\title{
Carbon nanomaterials as contrast agents for breast cancer diagnosis and therapy
}

\author{
Sara Dolci ${ }^{1}$, Valentina Domenici', Gianpaolo Vidili², Elisabetta Avitabile², Marco Orecchioni ${ }^{2}$, Alberto Bianco ${ }^{3}$, \\ Lucia Delogu ${ }^{2 *}$
}

From Breast Cancer Immunotherapy Symposium (BRECIS), part of the Sidra Symposia Series, held in partnership with the Society for Immunotherapy of Cancer

Doha, Qatar. 13-14 April 2015

Nanotechnology is the promise to fight breast cancer (BC) more specifically and effectively [1]. In this context carbon nanomaterials (CNs) have attracted the scientific community and the public interest [2]. Common modalities for BC diagnosis are ultrasonography (US) and magnetic resonance imaging (MRI). US is the most useful modality in the evaluation of palpable BC masses that are mammographically occult in women younger than 30's. Here we show CNs as highly and long lasting echogenic materials. Experiments on swine models confirmed that $\mathrm{CNs}$ are clearly visible under US and didn't exert toxicity. In the current market dual-imaging agents are missed; here we also demonstrate the immune-compatibility and high echogenic properties in water and in whole blood of cysteine functionalized super paramagnetic nanoparticles (CY-SPION), wellknown MRI agents [3]. Thanks to these findings, and the ability to load CNs to many moieties [4-6], we propose dual-contrast agents, CNs-CY-SPION conjugates, to improve $\mathrm{BC}$ diagnosis. Future perspectives is to conjugate $\mathrm{CN}$-SPION to targeted drugs against $\mathrm{BC}$. In summary, we lay the foundations for novel contrast agents, for therapy and multimodal diagnosis of $\mathrm{BC}$, combining high imaging performances with unique potential therapeutic applications, such as specific targeting capabilities, drug delivery, immunotherapy and hyperthermia.

\section{Authors' details}

${ }^{1}$ University of Pisa, Pisa, Italy. ${ }^{2}$ University of Sassari, Sassari, Italy. ${ }^{3} \mathrm{CNRS}$,

Institut de Biologie Moléculaire et Cellulaire, Laboratoire d'Immunologie et Chimie Thérapeutiques, Strasbourg, France.

${ }^{2}$ University of Sassari, Sassari, Italy

Full list of author information is available at the end of the article
Published: 14 August 2015

\section{References}

1. Avitabile E, Bedognetti D, Sgarella F, Delogu LG: Nanotechnology fight for breast cancer., (under preparation).

2. Sechi G, Bedognetti D, Sgarrella F, Van Eperen, L, Marincola FM, Bianco A, Delogu LG: The perception of nanotechnology and nanomedicine: a worldwide social media study. Nanomedicine 2014, 9(10):1475-86.

3. Dolci A, lerardic V, Gradi A, Jagli Z, Remskard M, Apihd T, Cifellia M, Pampalonia G, Veracinia CA, Domenici V: Precursors of Magnetic Resonance Imaging Contrast Agents Based on Cystine-coated Iron-oxide Nanoparticles. Current Physical Chemistry 2013, 3(4):493-500.

4. Delogu LG, Magrini A, Bergamaschi A, Rosato N, Dawson Ml, Bottini N: Conjugation of antisense oligonucleotides to PEGylated carbon nanotubes enables efficient knockdown of PTPN22 in T lymphocytes. Bioconjug Chem 2009, 18(20):427-431.

5. Delogu LG, Venturelli E, Manetti R, Pinna GA, Carru C, Madeddu R, Murgia L, Sgarrella $F$, Dumortier $H$, Bianco A: Ex vivo impact of functionalized carbon nanotubes on human immune cells. Nanomedicine (Lond) 2012, 7(2):231-243.

6. Modugno G, Ménard-Moyon C, Prato M, Bianco A: Carbon nanomaterials combined with metal nanoparticles for theranostic applications. $\mathrm{Br} J$ Pharmacol 2015, 172(4):975-91.

doi:10.1186/2051-1426-3-S1-P5

Cite this article as: Dolci et al:: Carbon nanomaterials as contrast agents for breast cancer diagnosis and therapy. Journal for ImmunoTherapy of Cancer 2015 3(Suppl 1):P5.

Submit your next manuscript to BioMed Central and take full advantage of:

- Convenient online submission

- Thorough peer review

- No space constraints or color figure charges

- Immediate publication on acceptance

- Inclusion in PubMed, CAS, Scopus and Google Scholar

- Research which is freely available for redistribution

Submit your manuscript at www.biomedcentral.com/submit
() Biomed Central 